https://doi.org/10.3126/batuk.v6i1.33252

THE BATUK : A Peer Reviewed Journal of Interdisciplinary Studies

Vol. 6, Issue No.1, Jan 2020, Page: 63-71

ISSN 2392-4802

\title{
Ralph Waldo Emerson's Approach to Ecology
}

\author{
Mohan Raj Gouli, PhD \\ Associate Professor, Nepal Sanskrit University \\ Visiting Faculty, Nesfield International College \\ Email: mohangauli@gmail.com
}

\begin{abstract}
This article attempts to explore Emerson's trust in nature and his efforts to establish strong affinity between human being and natural world using the tool of ecocriticism. Ecological study attempts to elaborate the significance of nature for the benefit of human beings. Protecting nature means protecting the life of human beings because when the nature is destroyed, it eventually hampers the daily life of human individuals. Nature writers have honestly recognized the value of nature to encourage people to love it and understand its value. Living beings undergo several experiences in the company of nature and they maintain their miseries and happiness which come side by side. Therefore, it is essential that human beings must honestly attempt to strengthen their understanding with the environmental issues.
\end{abstract}

Keywords: Ecology, Transcendental, Identity, Civilization, Sublime.

Ecology emphasizes to maintain equal status of living and nonliving things in the universe and the value of nature gets priority along with the value of human beings. Therefore, the main concern of ecology is to make the concerned people aware of nature's contribution to the survival of living creatures in the universe. Such belief enables the people to acknowledge the essential of environmental protection which ultimately strengthens our own existence. There is demand of keeping harmony with the environment rather than domination and trying to always get benefit ignoring their value to maintain normal situation in human beings' meaningful life.

Nature writers deal with ecological concepts in their writings. They have praised rain, mountains, trees, grass, rivers, birds, insects, wild animals, flowers, storms and deserts etc. so beautifully that human beings are tempted by these natural elements and begin to try to understand their mysteries and significance in their life. For instance, Laxmiprasad Devkota praises the rainy season exploring its vitality - "The trees in solitude like immobile pictures looked at the high piles, / You, waiting for the wind to bring the message from far away, / Listen to it now bowed heads, the orders of the Rain King" (17-19). The poet simultaneously welcomes the rain and wind praising their arrival in front of him. He also speaks about the trees which were 
eager to receive the rain water. Percy Bysshe Shelley speaks about the west wind and expresses his expectations, "Drive my dead thoughts over the universe / Like withered leaves to quicken a new birth!/ And, by the incantation of this verse," (6365). The poet takes the wind as source of new thoughts because he can renew his old thoughts with the help of such environment. Both Devkota and Shelley display their "complete ecological vision" (Rueckert 118) in their verse. Their descriptions of nature, of course, significantly inspire the people to understand its significant role to support human beings along with all animal and plant kingdoms in this universe.

For ecological reading perspective on literature, Ralph Waldo Emerson occupies significant role in discussing about the value of nature in the life of human beings. For him nature is a source of creations, energy and tranquility. His ideas are "appropriate for the increasingly material interests and scientific concepts of environmental scholarship" (Meehan 214).

He sometimes takes nature as a source of happiness; and at other times he also takes nature as a sight of mystery. In this regard, on the one hand he has produced very important texts that deal with nature and its great value in the universe and on the other hand he, according to Robert Finch and John Elder, he has "inspired" important "figures [such] as Thoreau, Burroughs, Whitman, and Muir". They further say that Emerson "reveals himself as an original observer and vivid recorder of local phenomena" (Robert Finch and John Elder 140-141). This paper examines how and why Emerson has been taken a practitioner of ecology in literature.

In his first book, Nature, Emerson takes nature as a source of all human creations. Nature carries the real truth on which people work and move forward to investigate on the sources given by it, "[N]ature is already, in its forms and tendencies, describing its own design. Let us interrogate the great apparition that shines so peacefully around us. Let us inquire, to what end is nature" (142). Emerson believes that people must isolate themselves from their artificial dwelling place and their community if they really want to understand the value of nature, "To go into solitude, a man needs to retire as much from his chamber as from society. I am not solitary whilst I read and write, though nobody is with me. But if a man would be alone, let him look at the stars" because there he can visualize "the perpetual presence of the sublime" (142). For Emerson, the presence of the stars enhances the beauty and wonderful images of happiness that make the people inter into the realm of sublimity. He enthusiastically acknowledges: 
The stars awaken a certain reverence, because though always present, they are inaccessible; but all natural objects make a kindred impression, when the mind is open to their influence. Nature never wears a mean appearance. Neither does the wisest man extort her secret, and lose his curiosity by finding out all her perfection. Nature never became a toy to a wise spirit. The flowers, the animals, the mountains, reflected the wisdom of his best hour, as much as they had delighted the simplicity of his childhood. (143)

Emerson evidently expresses his attitude towards nature in this passage. It is his profound attitude that foregrounds the impact of nature on an individual who can play with it. He emphasizes on being "open to their influence" to develop comprehensive power to be delighted with the real beauty of nature. He honestly speaks about the great resemblance of nature and her productive result in the life of every individual.

Emerson gets delighted to see nature and tries to convey the mystery of her beauty to the individuals. Through the images of different natural scenes, Emerson highlights the grandeur of nature in the following lines:

In the presence of nature a wild delight runs through the man, in spite of real sorrows. Nature says, - he is my creature, and maugre all his impertinent griefs, he shall be glad with me. Not the sun or the summer alone, but every hour and change corresponds to and authorizes a different state of the mind, from breathless noon to grimmest midnight. (143)

Nature can easily wipe out the misery of the people when they associate themselves with her in deeper level. Disappointment can no more stay with the people and create troublesome situation if they surrender themselves into the lap of nature because she holds multiple scenarios creating "different state of the mind" that helps liberate from the state of miseries and enjoy the life.

Human beings' identity and status are not beyond nature and natural activities. Belief in religion too is associated with respect of nature. Water, trees, stones air and light are worshiped by the people because they find the images of gods in them. We try to adjust ourselves as the parts of nature so that we can gain our strength and preserve ourselves from being destroyed. Joseph W. Meeker, in this context, is right to say:

Man is a part of nature and subject to all natural limitations and flaws. Morality is a matter of getting along with one's fellow creatures as well as 
possible. All beliefs are provisional, subject to change when they fail to produce harmonious consequences. Life itself is the most important force there is: the proper study of mankind is survival.' When the existence of many species, including the human, and the continuity of the biological environment are threatened as they are now, mankind can no longer afford the wasteful and destructive luxuries of a tragic view of life. (167)

Meeker strongly believes that the relationship between man and nature is intrinsic and he remains as "a part of nature" and he is naturally "subject to all natural limitations and flaws." He must try to show moral values to be in harmony with nature. In case of being unable to do this, he is bound undergo adverse results and he suffers from tragic situation.

Meeker advocates in favor of "return to nature" so that human beings can protect their civilization and lead their valuable life. As Emerson emphasizes on developing understanding the nature and natural activities around us, Meeker speaks about returning to nature and protecting themselves from being eliminated from the nature because nature cares each and every individuals- living or nonliving. They must not think that they are only to survive ignoring the identity of other natural elements. Meeker further says:

Human values could no longer be based on the assumption that man is alone at the center of creation; allowance would have to be made for the welfare of all the plants, animals, and land of the natural environment. Mankind would have to cultivate a new and more elaborate mentality capable of understanding intricate processes without destroying them. Ecology challenges mankind to vigorous complexity, not passive simplicity. (168)

These lines explicitly speak about ecological value in this world. Importance of human values is completely related to the importance of "all the plants, animals, and land of the natural environment." In ecology, all these elements occupy their special positions and their presence maintains ecosystem which is too much valuable for human beings to survive here. In this regard Sueellen Campbell quotes Emerson, "We are as much strangers in nature as we are aliens from God. We do not understand the notes of birds. The fox and the deer run away from us; the bear and tiger rend us" (quoted in "The Land and Language of Desire" 135).

Nature, for Emerson, is the source of tranquility and real delight can be achieved from it if the people attempt to acknowledge and create harmony with her in real 
sense, "[I]t is certain that the power to produce this delight does not reside in nature, but in man, or in a harmony of both. It is necessary to use these pleasures with great temperance. For nature is not always tricked in holiday attire" (Nature, 144). His conviction is that nature encompasses ample source of beauty and pleasures that can be of a great value to human beings, "In the wilderness, I find something more dear and connate than in streets or villages. In the tranquil landscape, and especially in the distant line of the horizon, a man beholds somewhat as beautiful as his own nature" (144).Thus, Emerson's concept of the value of nature is extraordinary and he pleads the people to develop such mental state that can felicitate the spirit of positive thought regarding nature and her effects on them. Denial Savage, in "Progressive Change in Emerson's The Conservative," praises Emerson's concept that a man must prove himself as "a restorer of truth and good" (127).

Emerson takes nature as a source of knowledge and inspiration that plays vital role to move forward in course of an individual's life. Our activities with nature leave deep impression with us and they remind us of past incidents and happenings that lead us in every step. In The Journals of Ralph Waldo Emerson, we get information about how he describes his impression with nature, "If you gather apples in the sunshine or make hay or hoe corn and then retire within doors and strain your body or squeeze your eyes six hours after, you shall still see apples hanging in the bright light with leaves and boughs thereto" because, according to Emerson, "There lie the impressions still on the retentive organ though I knew it not" (Nature, 147). After a person is acquainted with any natural images, he or she begins to develop a kind of association with such images that there is strong attachment between nature and that person.

The images of nature don't leave the people in isolation rather they always remain with them and remind them of their impressions of the past and human beings carry those impressions throughout their life. For instance, Emerson in his Journal dated September 8. [1840], remembers:

I went into the woods. I found myself not wholly present there. If I looked at a pine-tree or an aster, that did not seem to be Nature. Nature was still elsewhere: this, or this was but outskirt and far-off reflection and echo of the triumph that had passed by and was now at its glancing splendor and heyday, - perchance in the neighboring fields, or, if I stood in the field, then in the adjacent woods. Always the present object gave me this sense of the stillness that follows a pageant that has just gone by. (148) 
Emerson honestly seems to pay his homage to the past impressions of nature that had deeply rooted in his memory. For him real nature was not seen at present but it was in the past. He is haunted by "reflection and echo of the triumph" of the past. Although the present is with him and past is away from him, he is attracted by the past impressions of nature and its beauty that had penetrated into his mind and remained there forever.

Emerson, in Kathryn VanSpanckeren's words, "is remarkably consistent in his call for the birth of American individualism inspired by nature" (28). Emerson attempts to seek individual's freedom in his or her life and he believes that it can be only achieved when we understand the growth of natural elements in this universe. For him only nature can enable us to move forward enjoying our individual liberty. He begins his Nature (1836):

Our age is retrospective. It builds the sepulchers of the fathers. It writes biographies, histories, criticism. The forgoing generations beheld God and nature face to face; we, through their eyes. Why should not we also enjoy an original relation to the universe? Why should not we have a poetry of insight and not of tradition, and a religion by revelation to us, and not the history of theirs. Embosomed for a reason in nature, whose floods of life stream around and through us, and invite us by the powers they supply, to action proportioned to nature, why should we grope among the dry bones of the past...? (qtd. in VanSpanckeren 28)

Emerson finds nature as an ample source of inspiration to achieve individual emancipation without depending upon the past incidents and happenings. Therefore, he pleads the individuals not to be "retrospective" and try to "enjoy an original relation to the universe" which is easily available in front of us. For him, nature is the great source power. He urges people to be practical and lead a meaningful life from nature.

Emerson believes that human beings suffer when they are alienated from the world of nature. His attitudes toward nature are deeply rooted with his rejection of some formalities of the church:

From the time of his boyhood in Boston, Emerson was an independent and self-reliant individual whose career was an exemplum of his beliefs. After entering the Unitarian ministry, he became dissatisfied with the sacraments and formalized aspects of the church as an institution. (Inge 103) 
He loved to lead the life of independence and therefore, he desired to get rid of "the sacraments and formalized aspects of the church." Emerson's such attitudes diverted him toward nature and his inclination to nature seems very strong in his texts. He understood how nature worked independently and progressed without any formal rules and regulations as in the life of human beings who are unnecessarily guided by religious formality as rituals to exhibit their so called civilization.

Ralph Waldo Emerson's faith in nature enabled him to work along with transcendental inquiry, for he liked to like to get supreme knowledge rejecting traditional and conventional concepts of approaching the source of knowledge. He adhered in the process of getting into conscience of independent inquiry which is free from any rituals imposed by any outside agency that suffered from conventional ideas. In his famous essay entitled “Self-Reliance," Emerson writes:

There is time in every man's education when he arrives at the conviction that envy is ignorance; that imitation is suicide; that he must take himself for better [or] worse as his portion; that though the wide universe is full of good, no kernel of nourishing corn can come to him but through his toil bestowed on that plot of ground which is given to him to till. The power which resides in him is new in nature, and none but he knows what that is which he can do, nor does he know until he has tried. (104)

Emerson explicitly realizes that imitating knowledge from conventional sources of rituals lead us nowhere but to "ignorance" and it is like attempting to commit "suicide." Therefore, he advocates for getting knowledge from "the wide universe" which is ample source of everything required for an individual to enrich his/her transcendental search. His belief in the universe is symbolically speaks about nature from where we always get new references to enrich our transcendental feelings. Emerson desires to promote "biological rhythms" to borrow the words of Ferris Jabr.

Emerson's love for nature is related to his advocacy for the individual's identity which is badly affected by the routine works of divine rules propounded by the heads of religious institutions. He attempts to satirize such institutions and allures the individuals to follow the paths presented by nature in front of them. In "Uriel," Emerson presents: 
It felt in the ancient periods

When the brooding soul surveys,

Or ever the wild Time coined itself

Into calendar months and days. (1-4)

He considers that "the ancient periods" symbolize such time which is responsible to curtail the rights of the individuals because "[t]his was the lapse of Uriel/Which in Paradise befell" (5-6). The individuals are supposed to move in accordance with the rituals made in so called heaven. But on the other hand "[1]ine in nature is not found" (21) which means individual liberty is found in nature. In this context, Patrick Labriola has rightly remarked, "Emerson views nature as means of educating the individual about what is morally right and wrong" (127).

Therefore, Emerson pleads the people to perform their work depending upon the laws of nature, for there is free flow of life and we face no hindrances that mitigate our liberty and rights. He believes actual truth and charm of life can be only experienced by the people when they are guided by nature and her principles. $\mathrm{He}$ claims that nature encompasses enormous sources of energy, happiness and tranquility to make human beings lead their meaningful life. To achieve such qualities of natural world, Emerson insists people to pay attention to the mystery and wonderful acts of nature which are taking place around our surroundings.

\section{Works Cited}

Campbell, Sueellen. "The Land and Language of Desire." The Ecocentricism Reader: Landmarks in Literary Ecology. Eds. Glotfelty Cheryll, and Harold Fromm. University of Georgia Press, 1996. 124-36.

Devkota, Laxmi Prasad. “The Rain.” The Lunatic and Other Poems. Mahakavi

Laxmi Prasad Devkota Study and Research Centre, 2009. 165-69.

Emerson, Ralph Waldo. "From Nature." Nature Writing: The Tradition in English.

Eds. Robert Finch and John Elder. W. W. Norton \& Comp., 2002.141-44.

---. "Uriel." A Nineteenth-Century American Reader. $2^{\text {nd }}$ ed. Ed. M. Thomas Inge

Washington, D. C.: The United States Information Agency, 1995. 121-22.

Finch, Robert and John Elder, eds. Nature Writing: The Tradition in English. W. W. Norton \& Company, 2002.

Inge, M. Thomas, ed. A Nineteenth-Century American Reader. $2^{\text {nd }}$ ed. The United States Information Agency, 1995. 
Jabr, Ferirs. "The Earth Is Just as Alive as You Are."

https://www.nytimes.com/2019/04/20/opinion/sunday/amazon-earth-rainforest environment.html.

Labriola, Patrick. "Ralph Waldo Emerson's "Nature": Puritan Typology and German Idealism." The Concord Saunterer. 10 (2002): 124-33. Web. 29 Feb. 2020. https://www.jstor.org/stable/23392872.

Meehan, Sean Ross. ““The Best Read Naturalist”: Nature Writings of Ralph Waldo Emerson by Michael P. Branch and Clinton Mohs." Early American Literature. 53.1 (2018): 214-216. Web. 29 Feb. 2020. https://www.jstor.org/stable/10.2307/90019140.

Meeker, Joseph W. "The Comic Mode.” The Ecocentricism Reader: Landmarks in Literary Ecology. Eds. Glotfelty Cheryll, and Harold Fromm. University of Georgia Press, 1996. 155-69.

Rueckert, William. "Literature and Ecology: An Experiment in Ecocriticism." The Ecocentricism Reader: Landmarks in Literary Ecology. Eds. Glotfelty Cheryll, and Harold Fromm. University of Georgia Press, 1996. 105-23.

Savage, Daniel. "Progressive Change in Emerson's The Conservative." Humanitas. XXII.1 and 2 (2009). 125-42.

Shelley, Percy Bysshe. "Ode to the West Wind.” The Compact Bedford Introduction to Literature. Ed. Michael Meyer. $8^{\text {th }}$ ed. Bedford / St. Martin's, 2009. 794-96.

VanSpanckeren, Kathryn. Outline of American Literature. The United States Department of State, 1995. 28. 